\title{
An on-line pre-concentration system for determination of cadmium in drinking water using FAAS
}

\author{
Walter N.L. dos Santos ${ }^{a}$, , Jorge L.O. Costa ${ }^{a}$, Rennan G.O. Araujo ${ }^{a}$, \\ Djane S. de Jesus ${ }^{\mathrm{a}, \mathrm{b}}$, Antônio C.S. Costa ${ }^{\mathrm{a}}$ \\ ${ }^{a}$ Universidade Federal da Bahia, Instituto de Química, Salvador, Bahia 40170-290, Brazil \\ ${ }^{\mathrm{b}}$ Centro Federal de Educação Tecnológica da Bahia, Salvador, Bahia 40300-010, Brazil \\ Received 20 December 2005; received in revised form 8 March 2006; accepted 13 March 2006 \\ Available online 29 March 2006
}

\begin{abstract}
In the present paper, a minicolumn of polyurethane foam loaded with 4-(2-pyridylazo)-resorcinol (PAR) is proposed as pre-concentration system for cadmium determination in drinking water samples by flame atomic absorption spectrometry.

The optimization step was performed using two-level full factorial design and Doehlert matrix, involving the variables: sampling flow rate, elution concentration, buffer concentration and $\mathrm{pH}$.

Using the established experimental conditions in the optimization step of: $\mathrm{pH} 8.2$, sampling flow rate $8.5 \mathrm{~mL} \mathrm{~min}^{-1}$, buffer concentration $0.05 \mathrm{~mol} \mathrm{~L}^{-1}$ and elution concentration of $1.0 \mathrm{~mol} \mathrm{~L}^{-1}$, this system allows the determination of cadmium with detection limit (LD) $(3 \sigma / \mathrm{S})$ of $20.0 \mathrm{ng} \mathrm{L}^{-1}$ and quantification limit (LQ) $(10 \sigma / \mathrm{S})$ of $64 \mathrm{ng} \mathrm{L}^{-1}$, precision expressed as relative standard deviation (R.S.D.) of 5.0 and 4.7\% for cadmium concentration of 5.0 and $40.0 \mu \mathrm{gL}^{-1}$, respectively, and a pre-concentration factor of 158 for a sample volume of $20.0 \mathrm{~mL}$. The accuracy was confirmed by cadmium determination in the standard reference material, NIST SRM 1643d trace elements in natural water.

This procedure was applied for cadmium determination in drinking water samples collected from Salvador City, Bahia, Brazil. For five samples analyzed, the achieved concentrations varied from 0.31 to $0.86 \mu \mathrm{g} \mathrm{L}^{-1}$.
\end{abstract}

(C) 2006 Published by Elsevier B.V.

Keywords: Cadmium determination; Drinking water; FAAS; Pre-concentration

\section{Introduction}

Cadmium is one of the heavy metals more critical for the human health [1]. It enters the organism primarily via the alimentary and/or respiratory tract. It can be cause of diseases as: hypertension, arteriosclerosis, cancer, etc. [2]. Considering it, health organizations have established permissible limits for cadmium in food human, including drinking water [2,3]. The World Health Organization (WHO) established as $3 \mu \mathrm{gL}^{-1}$ the maximum permissible for this element in drinking water [2]. The limit established by Environmental Protection Agency (EPA) is $5 \mu \mathrm{g} \mathrm{L}^{-1}$ [3]. In Brazil, the limit fixed by Health Organization Brazilian Govern is $5 \mu \mathrm{g} \mathrm{L}^{-1}$ [4].

\footnotetext{
* Corresponding author. Tel.: +55 7132351 166; fax: +55 712355166 .

E-mail address: waltrs8@ hotmail.com (W.N.L. dos Santos).
}

Cadmium determination in drinking water samples could be carried out directly by electrothermal atomic absorption spectrometry (ETAAS) or by inductively coupled plasma mass spectrometry (ICP-MS), which have usually enough sensitivity. However, flame atomic absorption spectrometry (FAAS) and inductively coupled plasma optical emission spectrometry (ICP-OES), which are available techniques in most laboratories, require the use of a pre-concentration step in order to reach an appropriate level of sensitivity. Considering it, pre-concentration procedures for determination of cadmium traces by FAAS and ICP-OES are opportune and several pre-concentration procedures have been proposed for it [5-11].

Polyurethane foam has good properties as sorbent in solid phase extraction [12]. It was firstly used in on-line preconcentration system in method for zinc determination using molecular absorption spectrophotometry [13]. However, in the last years this sorbent has been very used in on-line pre- 
concentration system for metal determination using flame atomic absorption spectrometry $[14,15]$.

Multivariate techniques have been very applied for optimization of analytical methods $[16,17]$. Among these, the two-level full factorial design is one of the more used. It can be applied mainly for preliminary evaluation of the significance of experimental variables of the methods $[16,18]$. However, for determination of critical conditions, one of the options is use of Doehlert designs [16,19], which is a response surface methodology (RSM) that have been very applied for optimization of analytical methods [20,21].

In this paper is proposed an on-line pre-concentration system for cadmium determination in drinking water samples by flame atomic absorption spectrometry. In it, a minicolumn of polyurethane foam loaded with 4-(2-pyridylazo)-resorcinol (PAR) is used as solid phase. The optimization step was performed using factorial design and Doehlert matrix.

\section{Experimental}

\subsection{Apparatus}

A Varian (Mulgrave, Vic., Australia) Model SpectrAA 220 flame atomic absorption spectrometer was used for the analysis. The cadmium hollow cathode lamp was run under the conditions suggested by the manufacturer (current: $4.0 \mathrm{~mA}$ ). Wavelength $(228.8 \mathrm{~nm})$, the bandwidth of the slit $(0.5 \mathrm{~nm})$ and burner height $(13.5 \mathrm{~mm})$ had suggested values. The flame composition was: acetylene (flow rate: $2.0 \mathrm{~L} \mathrm{~min}^{-1}$ ) and air (flow rate: $13.5 \mathrm{~L} \mathrm{~min}^{-1}$ ). Aspiration flow rate was $4.0 \mathrm{~mL} \mathrm{~min}^{-1}$.

Two Alitea USA peristaltic pumps C-6 XV provided with Tygon tubes were used to propel all solutions and a Rheodyne 5041 model injection valve was used to switch the preconcentration/elution steps. All connections were made using fittings, unions and tees made of plastic and PEEK materials. The manifold was built up with PTFE tube of $0.5 \mathrm{~mm}$ bore.

A 300 ANALYSER pH meter was used to adjust medium $\mathrm{pH}$.

\subsection{Reagents}

Ultrapure water from a Milli-Q water purification system (Millipore) was used to prepare all solutions.

All reagents were of analytical grade. The laboratory glassware was kept overnight in a 5\% (v/v) nitric acid solution. Afterwards it was rinsed thoroughly with ultrapure water and dried in a dust-free environment.

- Cadmium(II) solution $\left(10.00 \mu \mathrm{g} \mathrm{mL}^{-1}\right)$ was prepared by diluting a $1000 \mu \mathrm{g} \mathrm{mL}^{-1}$ cadmium solution with a $1 \%$ hydrochloric acid solution.

- PAR solution $0.01 \%(\mathrm{w} / \mathrm{v})$ was prepared by dissolving $0.20 \mathrm{~g}$ PAR in $200 \mathrm{~mL}$ of ethanol.

- Tris buffer solution was prepared by dissolving $12.10 \mathrm{~g}$ of Tris-(hydroxymethyl)aminomethane (Merck) in $1000 \mathrm{~mL}$ of deionised water and $\mathrm{pH}$ was adjusted with hydrochloric acid.
- Hydrochloric acid solution $\left(1 \mathrm{~mol} \mathrm{~L}^{-1}\right)$ was prepared by direct dilution with water from the concentrated suprapur solution.

\subsection{Preparation of the minicolumn}

PAR solution in a concentration of $0.01 \%(\mathrm{w} / \mathrm{v})$ was percolated through the minicolumn containing about $0.1 \mathrm{~g}$ of polyurethane foam in a flow rate of $2.5 \mathrm{~mL} \mathrm{~min}^{-1}$ for $5 \mathrm{~min}$. After this system was washed with $1 \mathrm{~mol} \mathrm{~L}^{-1}$ sodium hydroxide solution for elimination of the excess of PAR reagent and afterwards with $1 \mathrm{~mol} \mathrm{~L}^{-1}$ nitric acid solution and water at the same flow rate in order to prevent any metal contamination [22].

\subsection{Continuous flow system}

The diagram of the flow system is shown in Fig. 1. The flow system was carried out using two peristaltic pumps fitted with Tygon tubes, one four-way valve and a minicolumn packed with polyurethane foam loaded with PAR, coupled to a flame atomic absorption spectrometer [14]. The flow system was operated in a volume-based mode, which a sample volume of $20.0 \mathrm{~mL}$ pumped at $8.5 \mathrm{~mL} \mathrm{~min}^{-1}$ was percolated through a minicolumn. Then, cadmium(II) ions are retained in the minicolumn as cadmium(II)-PAR complex, and the remaining solution is discharged. By switching the valve a stream of $1.0 \mathrm{~mol} \mathrm{~L}^{-1}$ hydrochloric acid (E) that flows at $5.5 \mathrm{~mL} \mathrm{~min}^{-1}$ displaces the cadmium complexed. This eluate is taken direct to the nebulizer-burner system of a flame atomic absorption spectrometer. Signals were measured as peak area by using instrument software.

(A)

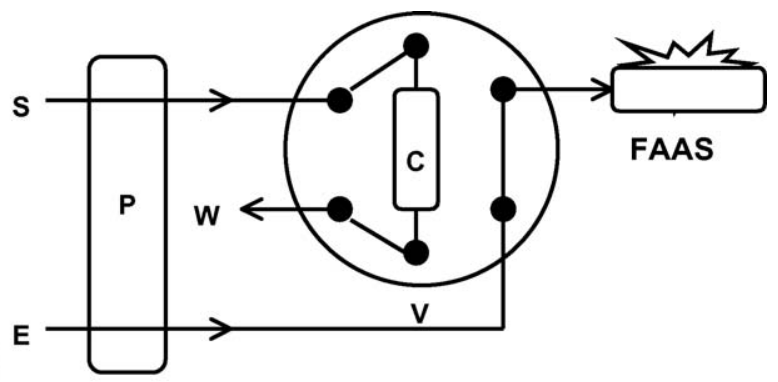

(B)

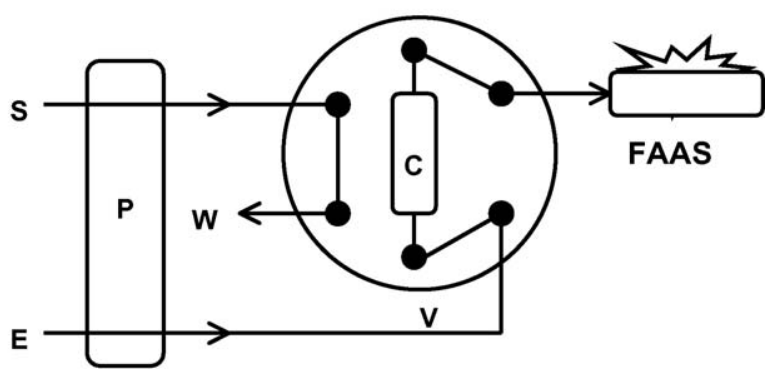

Fig. 1. System of on-line preconcentration. Schematic diagram of the flow system used for preconcentration and determination of cadmium by FAAS. P1 $\left(8.5 \mathrm{~mL} \mathrm{~min}^{-1}\right)$; P2 $\left(5.5 \mathrm{~mL} \mathrm{~min}^{-1}\right)$; P, peristaltic pump; C, polyurethane foam/PAR minicolumn; V, four-way valve; FAAS, flame atomic absorption spectrometer and W, waste. (A) Four-way valve in preconcentration step and (B) four-way valve in the elution position. 
The minicolumn was not reconditioned at the end of each cycle, since sample solution was buffered before preconcentration. This strategy has been recommended [23] in order to simplify the on-line system (an additional line with buffer solution is avoided) and to increase the concentration efficiency (CE). This strategy caused a small loss of the analyte, but it did not deteriorate the pre-concentration system, since this loss might be always reproducible for both standards and samples.

\subsection{Sample preparation}

The samples were conditioned in PTFA bottles, according (USEPA) recommendations [24]. In the laboratory, prior to the pre-concentration procedure, all the water samples were filtered through a $0.45 \mu \mathrm{m}$ pore size membrane filter to remove suspended particulate matter and were stored at $6^{\circ} \mathrm{C}$.

\subsection{Optimization strategy}

The optimization step was performed using two-level full factorial design and Doehlert matrix. All the experiments were carried out in random order, using always $20.0 \mathrm{~mL}$ of $5.0 \mu \mathrm{g} \mathrm{L}-1$ cadmium solution. The variables regarded as factors in this step were: sampling flow rate, elution concentration, buffer concentration and $\mathrm{pH}$. The elution flow rate was fixed at $5.5 \mathrm{~mL} \mathrm{~min}^{-1}$ because this is compatible with the aspiration flow of FAAS. The results of the factorial design and Doehlert matrix were evaluated using as response the analytical signal (absorbance).

\section{Results and discussion}

\subsection{Two-level full factorial design}

Considering the flow system, the variables chosen in the optimization step were: sampling flow rate (SFR), eluent concentration (EC), buffer concentration (BC) and pH. Firstly, a two level full factorial design was performed in order to determine the influence these factors on the on-line system. In Table 1 are the minimum and maximum levels of each factor, which were established according to data from previous experiments. Table 2 shows the experimental matrix and the results of this experiment. The evaluation considering the Pareto chart (Fig. 2) demonstrated that the interaction $(\mathrm{pH} \times$ buffer concentration) and the factors buffer concentration and $\mathrm{pH}$ are statistically significant. Sampling flow rate in the range from 7.0 to $10.0 \mathrm{~mL} \mathrm{~min}^{-1}$ and eluent concentration varied from 0.50 to $1.50 \mathrm{~mol} \mathrm{~L}^{-1}$ are not statistically significant.

Table 1

Factors and levels used in the factorial design

\begin{tabular}{lllc}
\hline Variables & Low (-) & Central point & High (+) \\
\hline Sampling flow rate (SFR), $\mathrm{mL} \mathrm{min}^{-1}$ & 7.0 & 8.5 & 10.0 \\
Buffer concentration (BC), mol L & & & \\
Elution concentration (EC), $\mathrm{mol} \mathrm{L}^{-1}$ & 0.010 & 0.055 & 0.100 \\
$\mathrm{pH}$ & 7.0 & 8.5 & 1.50 \\
\hline
\end{tabular}

Table 2

Two-level full factorial design

\begin{tabular}{llllll}
\hline Experiment & SRF & BC & EC & pH & AS \\
\hline 1 & + & + & + & + & 0.1340 \\
2 & + & + & + & - & 0.0546 \\
3 & + & + & - & + & 0.1436 \\
4 & + & + & - & - & 0.0812 \\
5 & + & - & + & + & 0.1000 \\
6 & + & - & + & - & 0.2482 \\
7 & + & - & - & + & 0.1056 \\
8 & + & - & - & - & 0.2510 \\
9 & - & + & + & + & 0.0710 \\
10 & - & + & + & - & 0.1367 \\
11 & - & + & - & + & 0.1458 \\
12 & - & + & - & - & 0.0785 \\
13 & - & - & + & + & 0.1005 \\
14 & - & - & + & - & 0.2570 \\
15 & - & - & - & + & 0.1106 \\
16 & - & - & - & - & 0.2482 \\
Central point & 0 & 0 & 0 & 0 & 0.2461 \\
Central point & 0 & 0 & 0 & 0 & 0.2570 \\
Central point & 0 & 0 & 0 & 0 & 0.2390 \\
\hline
\end{tabular}

Solution volume: $20 \mathrm{~mL}$; cadmium concentration: $5.0 \mu \mathrm{g} \mathrm{L}^{-1}$; SRF: sampling flow rate; $\mathrm{BC}$ : buffer concentration; EC: elution concentration; AS: analytical signal (absorbance).

\subsection{Determination of the critical conditions using Doehlert matrix}

Considering this result, a Doehlert design involving the factors buffer concentration (BC) and $\mathrm{pH}$ was carried out in order to determine the critical conditions of these variables for maximum signal of absorbance. In this design sampling flow rate and eluent concentration were fixed as $8.5 \mathrm{~mL} \mathrm{~min}^{-1}$ and $1.0 \mathrm{~mol} \mathrm{~L}^{-1}$, respectively. Table 3 shows the matrix as coded and real values and the analytical signals (AS) obtained in the Doehlert design. These results are fitted as the following equation:

$$
\begin{aligned}
& \mathrm{AS}=-0.525+0.185 \mathrm{pH}+1.018 \mathrm{BC}-0.011(\mathrm{pH})^{2}+0.068 \\
& \mathrm{pH} \mathrm{BC}-15.896(\mathrm{BC})^{2}
\end{aligned}
$$

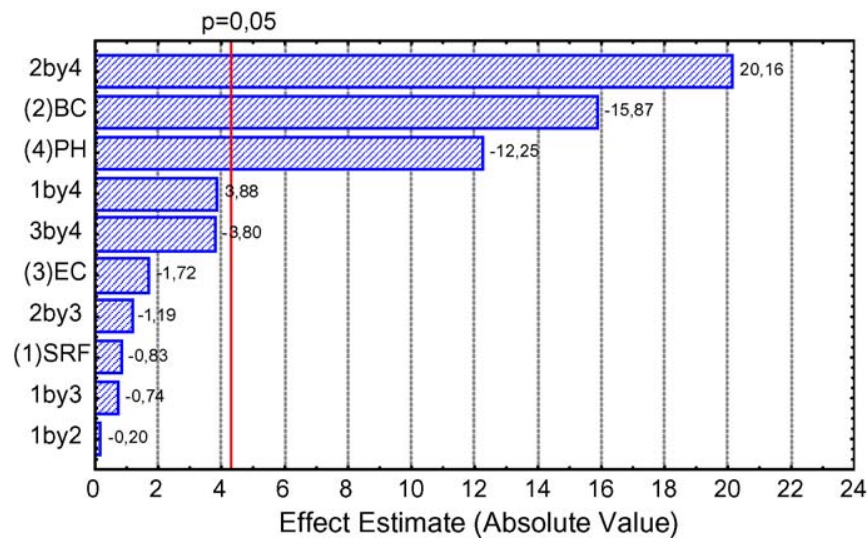

Fig. 2. Pareto chart of standardized effects. SRF: sampling flow rate; BC: buffer concentration; EC: elution concentration. 
Table 3

Doehlert matrix for optimization of $\mathrm{pH}$ and buffer concentration

\begin{tabular}{lll}
\hline $\mathrm{pH}$ & $\mathrm{BC}\left(\mathrm{mol} \mathrm{L}^{-1}\right)$ & $\begin{array}{l}\text { Analytical signal } \\
\text { (absorbance) }\end{array}$ \\
\hline $7.00(-0.866)$ & $0.070(0.5)$ & 0.2367 \\
$8.50(0.000)$ & $0.090(1.0)$ & 0.2358 \\
$10.00(0.866)$ & $0.070(0.5)$ & 0.2221 \\
$10.00(0.866)$ & $0.030(-0.5)$ & 0.2176 \\
$8.50(0.000)$ & $0.010(-1.0)$ & 0.2360 \\
$7.00(-0.866)$ & $0.030(-0.5)$ & 0.2403 \\
$8.50(0.000)$ & $0.050(0.0)$ & 0.2510 \\
$8.50(0.000)$ & $0.050(0.0)$ & 0.2651 \\
$8.50(0.000)$ & $0.050(0.0)$ & 0.2679 \\
\hline
\end{tabular}

The derivation of this equation in terms of $\mathrm{pH}$ and also $\mathrm{BC}$ results in the following equation system:

$\frac{\delta \mathrm{AS}}{\delta \mathrm{pH}}=+0.185-0.022 \mathrm{pH}+0.068 \mathrm{BC} ;$

$\frac{\delta \mathrm{AS}}{\delta \mathrm{BC}}=+1.018+0.068 \mathrm{pH}-31.792 \mathrm{BC}$

The resolution of this equation system shows a maximum point for $\mathrm{pH}$ of 8.23 and buffer concentration of $0.049 \mathrm{~mol} \mathrm{~L}^{-1}$. The corresponding surface response is shown in Fig. 3.

\subsection{Final optimization}

Considering the results obtained in the optimization step the conditions established in the procedure are: sampling flow rate of $8.5 \mathrm{~mL} \mathrm{~min}^{-1}$, buffer concentration of $0.05 \mathrm{~mol} \mathrm{~L}^{-1}$, $\mathrm{pH} 8.2$, elution concentration of $1.00 \mathrm{~mol} \mathrm{~L}^{-1}$ and elution flow rate of $5.5 \mathrm{~mL} \mathrm{~min}^{-1}$. The volumes used for samples and standard solutions in the preparation of the analytical curves are $20 \mathrm{~mL}$.

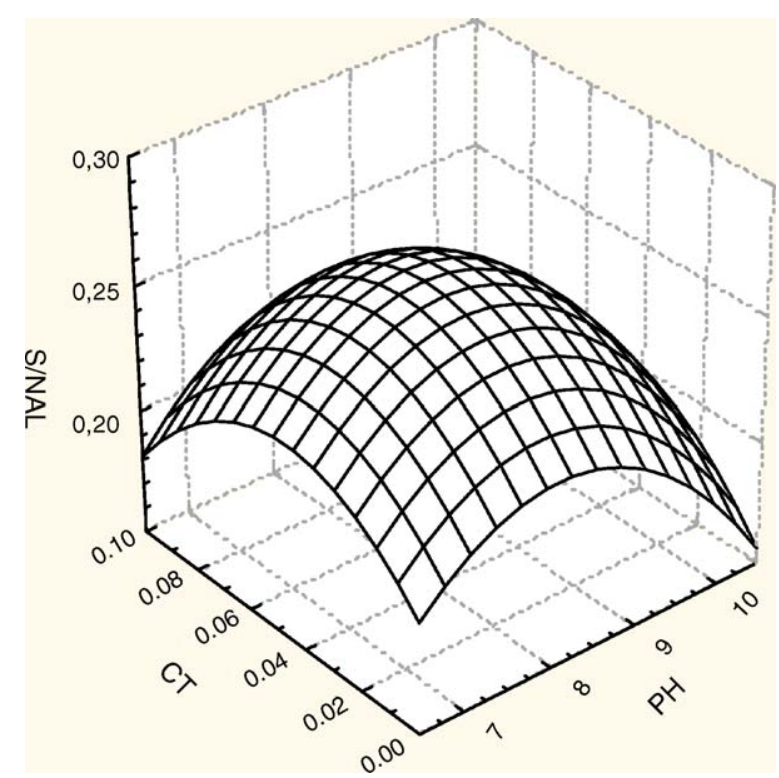

Fig. 3. Response surface for optimization of the variables $\mathrm{pH}$ and buffer concentration.

\subsection{Analytical characteristics}

The on-line pre-concentration system proposed showed linearity within the concentration range from $64 \mathrm{ng} \mathrm{L}^{-1}$ to $10.0 \mu \mathrm{g} \mathrm{L}^{-1}$, with an analytical curve of AS $=0.00122+0.0539$ $\left[\mathrm{Cd} \mu \mathrm{g} \mathrm{L}^{-1}\right]\left(R^{2}=0.9988\right)$. The precision expressed as relative standard deviation (R.S.D.) was 5.0 and $4.7 \%$ for cadmium concentration of 5.0 and $40.0 \mu \mathrm{g} \mathrm{L}{ }^{-1}$, respectively. A limit of detection (LD) of $20 \mathrm{ng} \mathrm{L}^{-1}$ and quantification (LQ) of $64 \mathrm{ng} \mathrm{L}^{-1}$ were calculated as IUPAC recommendation [25] for sample solution of $20 \mathrm{~mL}$. The experimental pre-concentration factor, calculated considering the ratio of the slopes of the analytical curves with and without pre-concentration was 158 . The consumptive index [23] (defined as the sample volume, in millilitres consumed in order to achieve a unit of factor preconcentration) was also calculate and was $0.13 \mathrm{~mL}$. The accuracy was confirmed by cadmium determination in the standard reference material, NIST SRM 1643d trace elements in natural water. Using the proposed method the cadmium concentration found in this SRM was $6.38 \pm 0.47 \mu \mathrm{g} \mathrm{L}^{-1}$ and the certified value of $6.47 \pm 0.37 \mu \mathrm{g} \mathrm{L}^{-1}$. The $t$-test demonstrated that there is no significant difference between these values.

\subsection{Tolerance of other metallic ions on the proposed procedure}

In order to check the effect of other metallic ions on the method, a standard solution containing cadmium and eighteen other metallic ions (each one at $10.00 \mu \mathrm{g} \mathrm{L}^{-1}$ ) was prepared and cadmium was determined. The achieved results showed that in this concentration, the other metallic ions do not interfere in the cadmium determination. This experiment was carried out using a multielemental ICP-OES solution Quality Control Standards (QCS-19), which had arsenic, antimony, beryllium, cadmium, calcium, chromium, cobalt, copper, iron, molybdenum, nickel, thallium, titanium, zinc, lead, magnesium, manganese and selenium at the concentration of $100 \mu \mathrm{g} \mathrm{L}^{-1}$ each one.

\subsection{Cadmium determination in drinking water}

The proposed method was applied for cadmium determination in drinking water samples collected in Salvador City, Brazil.

Table 4

Cadmium determination in drinking water samples

\begin{tabular}{lllc}
\hline $\begin{array}{l}\text { Sampling } \\
\text { station }\end{array}$ & $\begin{array}{l}\text { Cadmium content } \\
\text { added }\left(\mu \mathrm{g} \mathrm{L}^{-1}\right)\end{array}$ & $\begin{array}{l}\text { Cadmium content } \\
\text { achieved }\left(\mu \mathrm{g} \mathrm{L}^{-1}\right)\end{array}$ & Recovery (\%) \\
\hline 1 & 0.00 & $0.34 \pm 0.03$ & - \\
& 0.50 & $0.91 \pm 0.01$ & 114 \\
2 & 0.00 & $0.51 \pm 0.04$ & - \\
& 0.50 & $1.04 \pm 0.03$ & 106 \\
3 & 0.00 & $0.44 \pm 0.03$ & - \\
& 0.50 & $0.90 \pm 0.05$ & 92 \\
5 & 0.00 & $0.86 \pm 0.03$ & - \\
\hline
\end{tabular}

$N$, number of observations $=3$. 
The obtained results for analyse of five samples collected in several points of the city varied from 0.31 to $0.86 \mu \mathrm{gL}^{-1}$, as can be seen in Table 4. Recovery experiments were performed and the results varied from 92 to $114 \%$. These results demonstrated that the cadmium concentration is lower than the maximum permissible level $\left(5.0 \mu \mathrm{g} \mathrm{L}^{-1}\right)$ for drinking water considering the Health Organization of the Brazilian Govern [4].

\section{Conclusion}

The analytical features (precision, limit of detection and accuracy) achieved demonstrated the feasibility of the on-line system proposed for cadmium determination in drinking water samples using FAAS.

The Doehlert matrix allowed a fast and efficient optimization of the chemical and operational variables of the proposed procedure.

The cadmium content for the drinking water samples collected in Salvador City, Brazil were lower than the maximum permissible level $\left(5.0 \mu \mathrm{g} \mathrm{L}^{-1}\right)$ for cadmium in drinking water as Health Organization of the Brazilian Government.

\section{References}

[1] A.C. Davis, P. Wu, X.F. Zhang, X.D. Hou, B.T. Jones, Determination of cadmium in biological samples, Appl. Spectrosc. Rev. 41 (1) (2006) 35-75.

[2] World Health Organization (WHO), Guidelines for Drinking Water Quality, Health Criteria and Other Supporting Information, vol. 2, 2nd ed., World Health Organization, Geneva, 1998.

[3] Environmental Protection Agency, EPA. Edition of the drinking water standards and health advisories, EPA 822-R-02-38, Washington, DC, 2002, http://www.epa.gov/waterscience/drinking/standards.html.

[4] Health ministry from Brazil, Ministério da Saúde, Portaria 518, 2004.

[5] M. Soylak, I. Narin, M. Dogan, Trace enrichment and atomic absorption spectrometric determination of lead, copper, cadmium and nickel in drinking water samples by use of an activated carbon column, Anal. Lett. 30 (15) (1997) 2801-2810.

[6] S. Cerutti, L.D. Martinez, R.G. Wuilloud, Knotted reactors and their role in flow-injection on-line preconcentration systems coupled to atomic spectrometry-based detectors, Appl. Spectrosc. Rev. 40 (1) (2005) 71-101.

[7] M. Soylak, Y. Akkaya, L. Elci, Flame atomic absorption spectrometric determination of $\mathrm{Cu}(\mathrm{II}), \mathrm{Co}(\mathrm{II}), \mathrm{Cd}(\mathrm{II}), \mathrm{Fe}(\mathrm{III})$ and $\mathrm{Mn}$ (II) in ammonium salts and industrial fertilizers after preconcentration/separation on Diaion HP-20, Int. J. Environ. Anal. Chem. 82 (2002) 197-206.

[8] M.A. Bezerra, M.A.Z. Arruda, S.L.C. Ferreira, Cloud point extraction as a procedure of separation and pre-concentration for metal determination using spectroanalytical techniques: a review, Appl. Spectrosc. Rev. 40 (2005) 269-299.
[9] A. Sharma, K.G. Bhattacharyya, Azadirachta indica (Neem) leaf powder as a biosorbent for removal of $\mathrm{Cd}$ (II) from aqueous medium, J. Hazard. Mater. 125 (2005) 102-112.

[10] M. Tuzen, K. Parlar, M. Soylak, Enrichment/separation of cadmium(II) and lead(II) in environmental samples by solid phase extraction, J. Hazard. Mater. 121 (2005) 79-87.

[11] S. Cerutti, S.L.C. Ferreira, J.A. Gasquez, R.A. Olsina, L.D. Martinez, Optimization of the preconcentration system of cadmium with 1(2thiazolylazo)-p-cresol using a knotted reactor and flame atomic absorption spectrometric detection, J. Hazard. Mater. 112 (2004) 279-283.

[12] T. Braun, J.D. Navratil, A.B. Farag, Polyurethane Foam Sorbents in Separation Science, CRC Press, Boca Raton, FL, 1985.

[13] D.S. Jesus, R.J. Casella, S.L.C. Ferreira, M.S. Carvalho, A.C.S. Costa, R.E. Santelli, Polyurethane foam as a sorbent for continuous flow analysis: preconcentration and spectrophotometric determination of zinc in biological materials, Anal. Chim. Acta 366 (1998) 263-269.

[14] W.N.L. dos Santos, C.M.C. Santos, S.L.C. Ferreira, Application of three-variables Doehlert matrix for optimization of an on-line preconcentration system for zinc determination in natural water samples by flame atomic absorption spectrometry, Microchem. J. 75 (3) (2003) 211221.

[15] W.N.L. dos Santos, C.M.C. Santos, J.L.O. Costa, H.M.C. Andrade, S.L.C. Ferreira, Multivariate optimization and validation studies in on-line preconcentration system for lead determination in drinking water and saline waste from oil refinery, Microchem. J. 77 (2004) 123-129.

[16] D.L. Massart, B.G.M. Vandeginste, S.N. Deming, Y. Michotte, F. Kaufman, Chemometrics: A Textbook, Elsevier, Amsterdam, 1998

[17] D.C. Montgomery, Design and Analysis of Experiments, 4th ed., Wiley, New York, 1997.

[18] C.R.T. Tarley, S.L.C. Ferreira, M.A.Z. Arruda, Use of modified rice husks as a natural solid adsorbent of trace metals: characterisation and development of an on-line preconcentration system for cadmium and lead determination by FAAS, Anal. Chim. Acta 77 (2004) 163

[19] S.L.C. Ferreira, W.N.L. dos Santos, C.M. Quintela, B.B. Neto, J.M. Bosque-Sendra, Doehlert matrix: a chemometric tool for analytical chemistry-review, Talanta 63 (2004) 1061-1067.

[20] A.C. Ferreira, A.C.S. Costa, M. das, G.A. Korn, Preliminary evaluation of the cadmium concentration in seawater of the Salvador City, Braz. Microchem. J. 78 (2004) 77-83.

[21] M.C.B. Quaresma, R.J. Cassella, M. de, F.B. Carvalho, R.E. Santelli, Focussed microwave-assisted sample preparation: total phenol determination in petroleum refinery effluents by flow injection spectrophotometry, Microchem. J. 78 (2004) 35-40.

[22] S.L.C. Ferreira, V.A. Lemos, B.C. Moreira, A.C.S. Costa, An on-line continuous flow system for copper enrichment and determination by flame atomic absorption spectroscopy, Anal. Chim. Acta 403 (2000) 259-264.

[23] Z. Fang, Flow Injection Separation and Preconcentration, VCH Weinheim, New York, 1993.

[24] USEPA, United States Environmental Protection Agency, (1669) Method Sampling Ambient Water for Trace Metals at EPA Water Quality Criteria Levels.

[25] IUPAC, Analytical Chemistry Division, Spectrochim. Acta: Part B, 33 (1978) 242. 